DOI: $10.5277 /$ epe 160112

\title{
REMOVAL OF REACTIVE BLUE 29 DYE BY ADSORPTION ON MODIFIED CHITOSAN IN THE PRESENCE OF HYDROGEN PEROXIDE
}

\begin{abstract}
Industrial effluents that carry dyestuff into natural water systems are serious environmental concern. Complex aromatic structures of dyes make them more stable and more difficult to remove from the effluents discharged into water bodies. In the present study, removal of reactive blue 29 dye with chitosan and modified chitosan with $\mathrm{Cu}$ complexes from aqueous solution was investigated in a batch adsorption system with respect to the changes in the contact time, $\mathrm{pH}$ of solution and chitosan dosage. Adsorption isotherms of the dye onto chitosan were also studied. The results revealed that the adsorption capacity of chitosan with $\mathrm{Cu}$ complexes is lower than that of chitosan without $\mathrm{Cu}$ complexes. Also effect of $\mathrm{H}_{2} \mathrm{O}_{2}$ on adsorption when we used chitosan without $\mathrm{Cu}$ complexes is more considerable. The results also demonstrated that adsorption capacity of reactive blue 29 dye on chitosan was higher at lower pHs. Finally, the Langmuir isotherm showed the best conformity to the equilibrium data.
\end{abstract}

\section{INTRODUCTION}

Wastewater generated by dyestuff production industry and many other industries which use dyestuffs and pigments are reported to have high color and organic content. According to Zollinger et al. [1], about 100000 various commercial dyestuffs and pigments exist and over $7 \times 10^{5} \mathrm{t}$ are produced annually in the world. The share of textile industry in discharging these chemical compounds to waste streams is ca. 10-15\% [2].

The discharge of highly colored waste is not only aesthetically displeasing but also impedes light penetration, thus upsetting biological processes within a stream. In addition, many dyestuffs are toxic to some organisms and may cause direct destruction of

${ }^{1}$ Department of Environmental Health Engineering, School of Public Health, Birjand University of Medical Sciences, Birjand, Iran.

${ }^{2}$ Department of Environmental Health Engineering, School of Public Health, and Center for Air Quality Research, Institute for Environmental Research, Tehran University of Medical Sciences, Tehran, Iran, corresponding author, e-mail: rnabizadeh@tums.ac.ir 
aquatic communities. Hence, the removal of dyestuffs from such wastewater is necessary [3].

The most widely used methods for removing dyestuffs from wastewater systems can be divided into three categories: biological, chemical and physical [4] ones. Although the biological treatment seems to be the most economical compared to physical and chemical processes, due to complex chemical structure and synthetic organic origin of dyes these compounds are not totally degraded [5]. Furthermore, they are proved to be highly stable against oxidizing agents [6]. Chemical methods include coagulation or flocculation combined with flotation and filtration, precipitation-flocculation with $\mathrm{Fe}(\mathrm{II}) / \mathrm{Ca}(\mathrm{OH})_{2}$, electroflotation, electrocoagulation, conventional oxidation methods by oxidizing agents (ozone), irradiation or electrochemical processes [7]. Although these methods are efficient for treatment of waters contaminated with pollutants, they are very costly and commercially unattractive. The high electrical energy demand and the consumption of chemical reagents are common problems [8]. Different physical methods are also widely used, such as membrane filtration processes (nanofiltration, reverse osmosis, electrodialysis) and adsorption techniques [9]. Major disadvantages of the membrane processes are: (1) limited lifetime before membrane fouling occurs and (2) cost of periodic replacements which need to be included in any analysis of their economic viability. Abundant literature data suggest liquid phase adsorption as one of the most popular methods for dye removal in aquatic solutions, especially for water and wastewater effluent. If properly designed, the adsorption process will produce high-quality treated effluent $[8,10]$. The application of nanomaterials for the removal of dyes from the effluents was studied extensively and one common nanomaterials used in this respect are carbon nanotubes [11].

Application of a new non-soluble and non-porous complex with copper ion based on ethylene glycol diglycidyl ether (EGDE), methacrylic acid (MAA) and 2-methylimidazole (2MI) (which is a synthetic polyampholyte) in decolorization of an azo dye methyl orange (MO) was experienced by Martinez et al. [12] and removal of methyl orange higher than $90 \%$ was achieved in $20 \mathrm{~min}$ at $\mathrm{pH} 7.0$, combining $0.8 \mathrm{mM}$ of complexed copper ions in the mixture with $24 \mathrm{mM}$ hydrogen peroxide. The dye adsorbed on the polyampholyte following a L4-type isotherm with $4.9 \mu \mathrm{mol} \cdot \mathrm{g}^{-1}$ maximum loading capacity and $3.1 \mu \mathrm{M}$ dissociation constant for the first monolayer.

Use of natural and cost effective materials capable of removing dyes from wastewaters is considered a competitive option among possible treatment methods. chitosan, as a natural polyampholyte, is derived from chitin. It is obtained by deacetylation of chitin under alkaline conditions. When the degree of deacetylation reaches ca. 50\%, chitin becomes soluble in aqueous acidic media. The solubilization occurs by protonation of the $\mathrm{NH}_{2}$ functional group on the $\mathrm{C}-2$ position of the D-glucosamine repeating unit, whereby the polysaccharide is converted to a polyelectrolyte in acidic media. The presence of $\mathrm{NH}_{2}$ groups in chitosan is the reason why it exhibits much greater potential compared with chitin for use in different applications. It is a special biopolymer having 
good properties including biodegradability, biocompatibility and antibacterial activity so it is interesting as a novel type of functional material [13]. Chitosan has a wide range of applications. Some of the potential applications of this biopolymer are in the areas of medicine, drug delivery, water treatment, membranes, hydrogels, adhesives, antioxidants, biosensors, and food packaging [14].

Recently, use of chitosan as an adsorbent has attracted attention in water and wastewater treatment industries due to its high content of amino and hydroxyl functional groups. This polysaccharide, which is deacetylated form of chitin, shows high potential for adsorption of dyes, metal ions, and proteins, beside its previously mentioned properties. Excellent adsorption characteristics of chitosan are due to following factors [15]:

- high hydrophilicity of chitosan owing to large number of hydroxyl groups,

- large number of primary amino groups with high activity as adsorption sites,

- flexible structure of chitosan polymer chain which enables one to adopt suitable configuration for complexation with metal ions. By immobilizing some ligands with high affinity to specified metal ions onto polymer matrices of chitosan by the chemical modification as such, it is expected to further improve the adsorption characteristics of chitosan.

In this work, the removal efficiency of reactive blue 29 dye in aquatic solution using chitosan as a natural polyampholyte combined with copper and hydrogen peroxide was investigated. In other words, a combination of adsorption and oxidation process was investigated to provide a simple, effective, and economic method for decontamination of aquatic solution. The effect of $\mathrm{pH}$, concentration of hydrogen peroxide, and various concentrations of chitosan were studied.

\section{MATERIALS AND METHODS:}

Materials. Chitosan of medium molecular weight (CAS No. 9012764) was used in this study. Samples of chitosan flakes with average molecular weights $105-106 \mathrm{~g} / \mathrm{mol}$ and with the deacetylation percentage of approximately $88.92 \%$, prepared from shells of shrimps were purchased from the Aldrich Company. Molecular structure of chitosan is shown in Fig. 1.

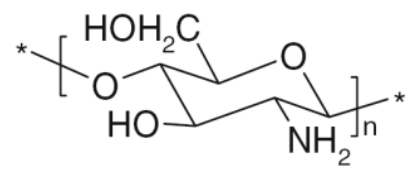

Fig. 1. Structural formula of chitosan

The commercial reactive blue 29 dye (RB29, chemical formula $\mathrm{C}_{31} \mathrm{Cl}_{2} \mathrm{H}_{19} \mathrm{~N}_{5} \mathrm{O}_{9} \mathrm{~S}_{2} \mathrm{Na}_{2}$, molecular weight $788 \mathrm{~g} / \mathrm{mol}$; maximum absorbance wavelength $589 \mathrm{~nm}$ ) was supplied 
from the Sigma Aldrich Company and was used without any further purification. Figure 2 displays the structural formula of reactive blue 29 dye. Doubly distilled water was used to prepare solutions

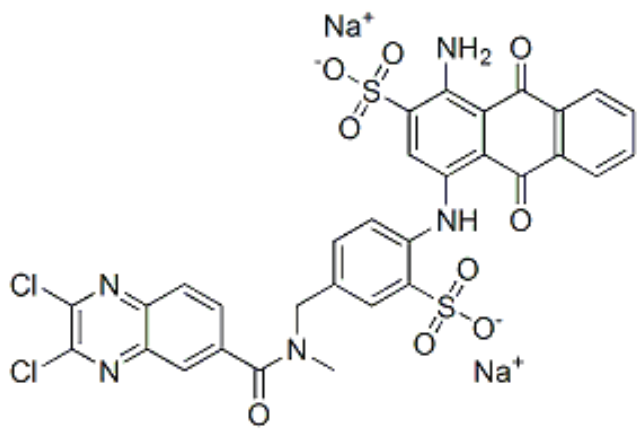

Fig. 2. Molecular structure of RB29

Arranging of the experiments. This study was performed as follows. At first, adsorption of chitosan- $\mathrm{Cu}(\mathrm{II})$ complexes and that of chitosan alone was investigated. After dosage of RB29 and chitosan solution into the Erlenmeyer flask, hydrogen peroxide was added. Then adsorption of chitosan was studied without using $\mathrm{Cu}$ (II) complexes or hydrogen peroxide. Finally, adsorption performances of all three systems were compared.

Preparation of chitosan-copper complex. Chitosan-copper complex was synthesized according to the procedure described elsewhere [12]. $0.100 \mathrm{~g}$ of chitosan were added to $2.0 \mathrm{~cm}^{3}$ of $80 \mathrm{mM} \mathrm{CuSO}_{4}$ solution in deionized water. Then the sample was centrifuged and filtered after $48 \mathrm{~h}$ contact time [12].

Hydrogen peroxide solutions. Hydrogen peroxide solutions of concentrations equal to $10,20,40,100,400$ and $800 \mathrm{mg} / \mathrm{dm}^{3}$ were prepared by diluting stock $30 \% \mathrm{H}_{2} \mathrm{O}_{2}$ solution (Merck) with deionized water.

Batch adsorption experiments. $5.312 \mathrm{mg}$ of RB29 were dissolved in $1 \mathrm{dm}^{3}$ of deionized water to prepare dye solution. Its concentration was constant in all batch experiments. $50 \mathrm{~cm}^{3}$ of that solution was mixed with a required dose of chitosan. The ratios $(R)$ of chitosan mass $(\mathrm{mg})$ to volume of RB29 solution varied from 0.25 to 5.0. For example, to get $R=0.25,12.5 \mathrm{mg}$ of chitosan was added to $50 \mathrm{~cm}^{3}$ of dye solution. The weighed amounts of chitosan needed to obtain $R$ equal to $0.5,1,1.5,2.5$ and 5 were 25 , 50,75125 and $250 \mathrm{mg}$, respectively. To achieve such $R, 50 \mathrm{~cm}^{3}$ of RB29 was added to chitosan solutions of different concentrations in $150 \mathrm{~cm}^{3}$ Erlenmeyer flasks. The Erlenmeyer flasks were placed on a magnetic stirrer at $25^{\circ} \mathrm{C}$ and were shaken until reaching 
equilibrium. $\mathrm{pH}$ of the solutions was adjusted to 7 using $0.1 \mathrm{M} \mathrm{HNO}_{3}$ and $0.1 \mathrm{M} \mathrm{NaOH}$. When studying the $\mathrm{pH}$ effect, its range of 2-12 was chosen.

After reaching to equilibrium state, the suspension was filtered through a $0.2 \mu \mathrm{m}$ filter for separation of the adsorbent and the filtrate was analyzed at the wavelength of $589 \mathrm{~nm}$ using a DR 5000 spectrophotometer $(\mathrm{HACH})$. The detection limit for this method was $0.03 \mathrm{mg} / \mathrm{dm}^{3}$ color value. The amount of RB29 adsorbed by chitosan or chitosan-copper complex was calculated from [16]:

$$
q_{e}=\frac{\left(C_{0}-C_{e}\right) V}{m}
$$

Where $q_{e}$ is the amount of RB29 adsorbed by chitosan or chitosan-copper complex $(\mathrm{mg} / \mathrm{g})$ in equilibrium state, $C_{0}$ is the initial RB29 concentration $\left(\mathrm{mg} / \mathrm{dm}^{3}\right), C_{e}$ is the final RB29 concentration at equilibrium state $\left(\mathrm{mg} / \mathrm{dm}^{3}\right), V$ is the initial solution volume $\left(\mathrm{dm}^{3}\right)$ and $m$ is the chitosan or chitosan-copper complex dosage (g).

Adsorption isotherms. In order to determine adsorption equilibrium isotherms we selected the initial concentration of the RB29 to $8.134 \mathrm{mg} / \mathrm{dm}^{3}$ and $R$ from 0.0625 to 1 . The weighed samples of chitosan needed to get the $R$ equal to $0.0625,0.125,0.25,0.5$ and 1 were $3.12,6.25,12.5,25$ and $50 \mathrm{mg}$, respectively. They were added to $50 \mathrm{dm}^{3}$ of the RB29 solutions. At higher $R$, the effluent concentrations of RB29 were equal to zero. The samples were kept under stirring until the adsorption equilibrium was reached. Then the effluent concentrations of $\mathrm{RB} 29$ or $\mathrm{C}_{e}$ were determined.

\section{RESULTS AND DISCUSSION}

\subsection{EFFECT OF CONTACT TIME AND CONCENTRATION OF ADSORBENT ON THE PROCESS EFFICIENCY}

The possible mechanisms of the adsorption process of the RB29 on chitosan in aqueous solution are likely to be ionic interactions of the dye ions with the amino groups of the chitosan as the following [17]:

$$
\begin{gathered}
\mathrm{D}-\mathrm{SO}_{3} \mathrm{Na} \rightarrow \mathrm{D}-\mathrm{SO}_{3}^{-}+\mathrm{Na}^{+} \\
\mathrm{R}-\mathrm{NH}_{2}+\mathrm{H}^{+} \rightarrow \mathrm{R}-\mathrm{NH}_{3}^{+} \\
\mathrm{R}-\mathrm{NH}_{3}^{+}+\mathrm{D}-\mathrm{SO}_{3}^{-} \rightarrow \mathrm{R}-\mathrm{NH}_{3}-3 \mathrm{~S}-\mathrm{D}
\end{gathered}
$$

First, sulfonate groups of RB dissociate and are converted to anions (1). In the presence of $\mathrm{H}^{+}$ions, amino groups of chitosan become protonated (2). Then the adsorption 
proceeds due to the electrostatic attraction between these two counter ions (3). The equilibrium saturation capacities of chitosan-Cu complex towards RB29 are demonstrated in Figs. 3-9. It is clear that the amount of RB29 adsorbed increased rapidly during about 20 min for all $R$ values and then the removal efficiency is kept constant. Chitosan (without $\mathrm{Cu}$ complex) sorption capacities are presented in Figs. 10-16.

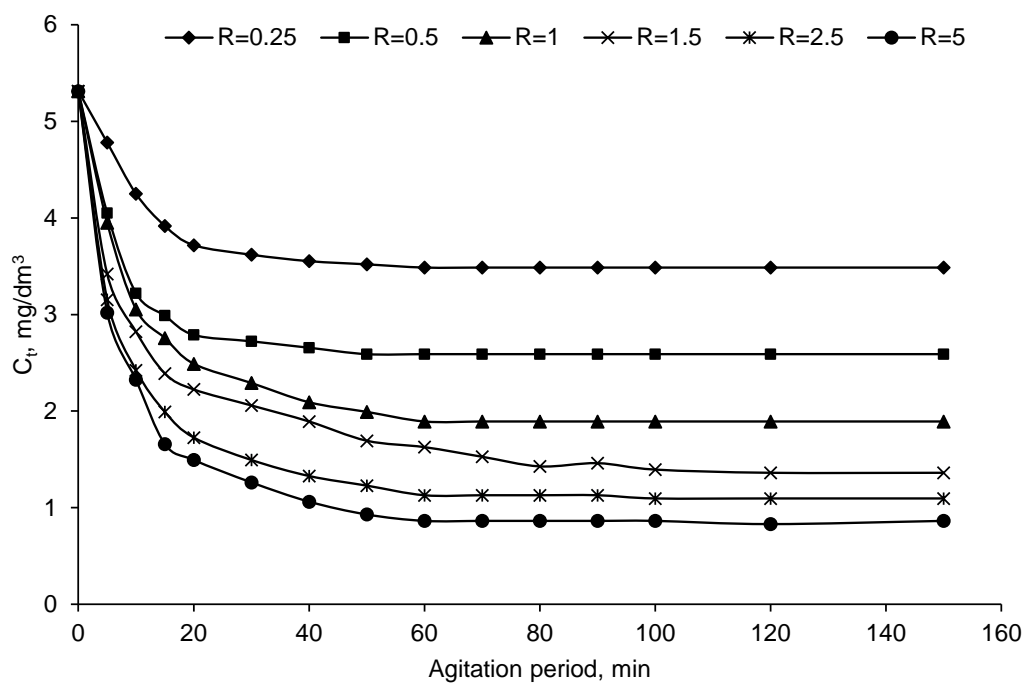

Fig. 3. Effect of contact time for chitosan-Cu(II) complex without $\mathrm{H}_{2} \mathrm{O}_{2}$ on $\mathrm{RB} 29$ adsorption efficiency

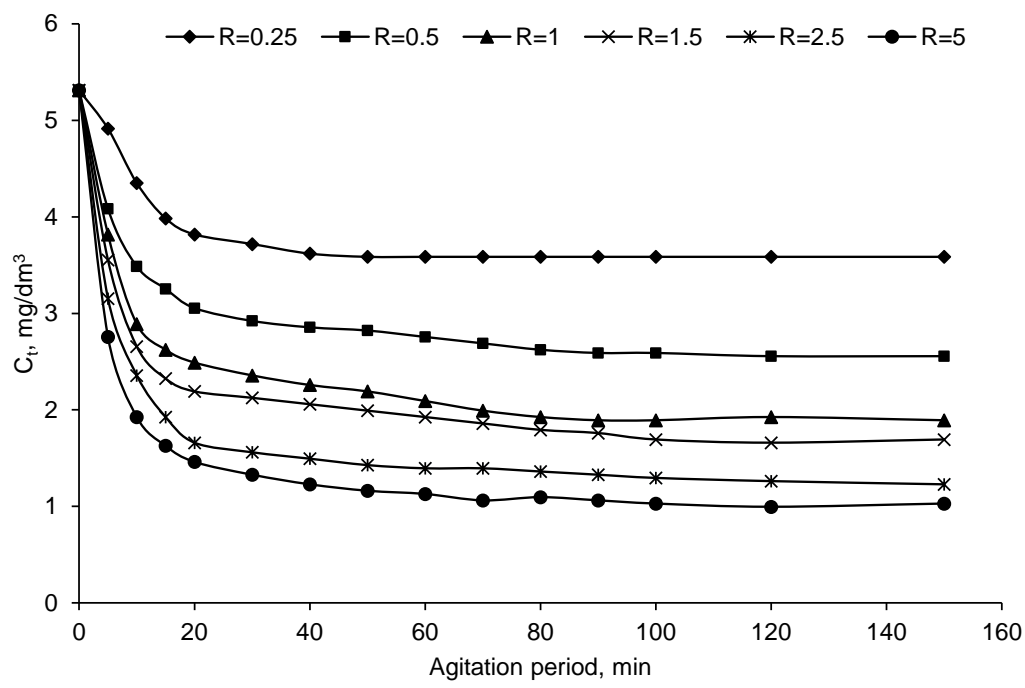

Fig. 4. Effect of contact time for chitosan-Cu(II) complex on RB29 adsorption efficiency (concentration of $\mathrm{H}_{2} \mathrm{O}_{2}-10 \mathrm{mg} / \mathrm{dm}^{3}$ ) 
Figure 3 shows the effect of contact time on adsorption of the RB29 by chitosan $-\mathrm{Cu}$ (II) complex without addition of $\mathrm{H}_{2} \mathrm{O}_{2}$. For $R=0.25$, the final concentration of the RB reached $3.48 \mathrm{mg} / \mathrm{dm}^{3}$ after $60 \mathrm{~min}$. The final concentration of dye decreased upon increasing $R$ and reached $0.86 \mathrm{mg} / \mathrm{dm}^{3}$ for $R=5$ after $60 \mathrm{~min}$ of contact time.

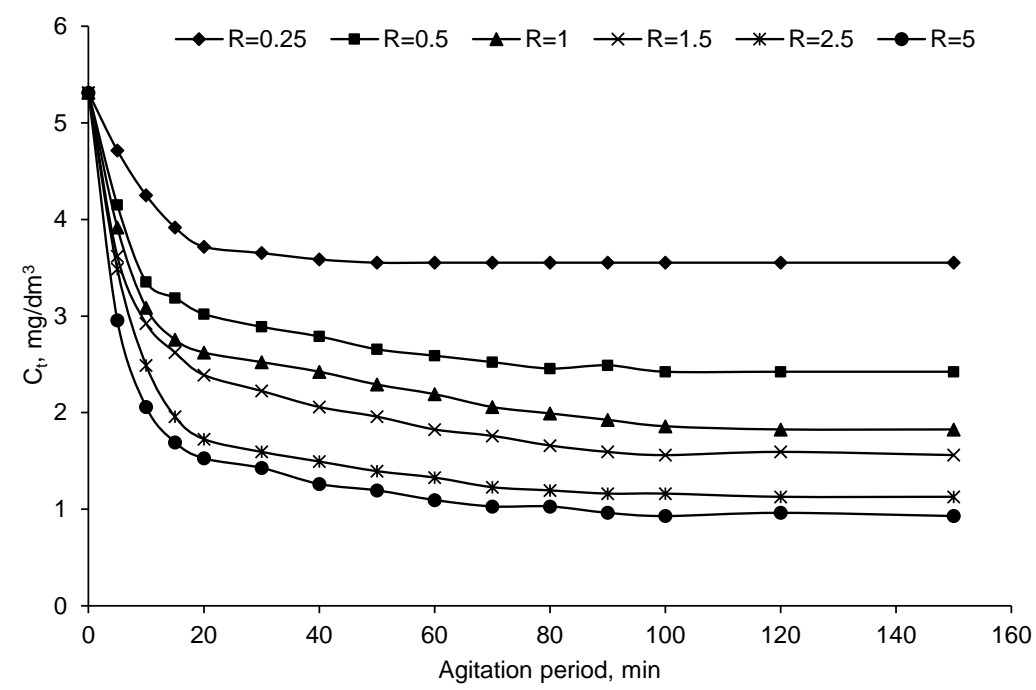

Fig. 5. Effect of contact time for chitosan-Cu(II) complex on RB29 adsorption efficiency (concentration of $\mathrm{H}_{2} \mathrm{O}_{2}-20 \mathrm{mg} / \mathrm{dm}^{3}$ )

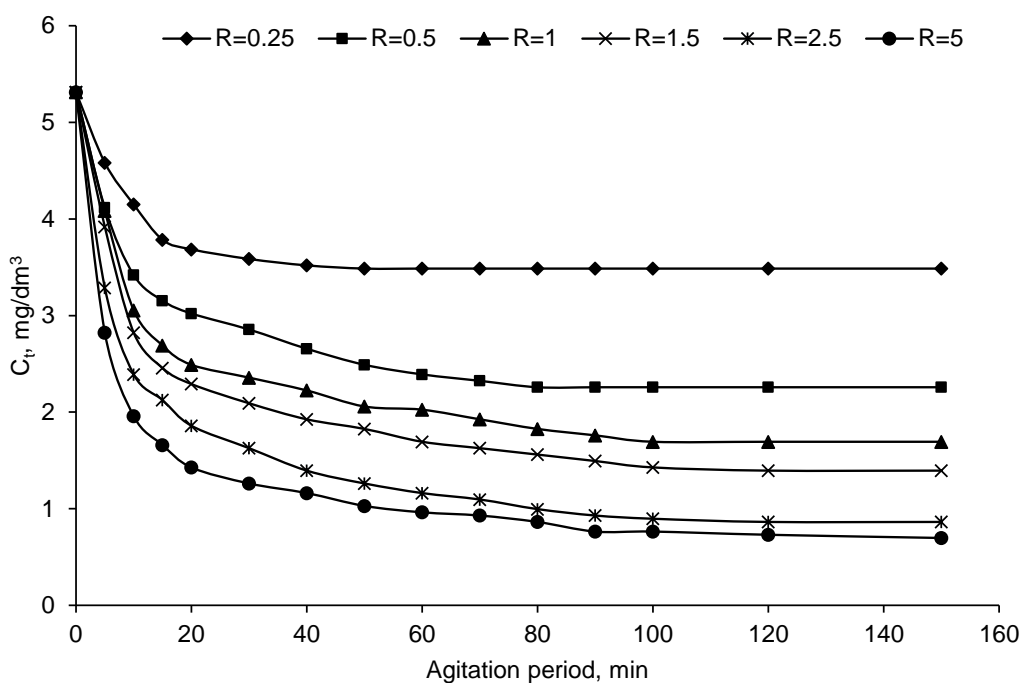

Fig. 6. Effect of contact time for chitosan-Cu(II) complex on RB29 adsorption efficiency (concentration of $\mathrm{H}_{2} \mathrm{O}_{2}-40 \mathrm{mg} / \mathrm{dm}^{3}$ ) 


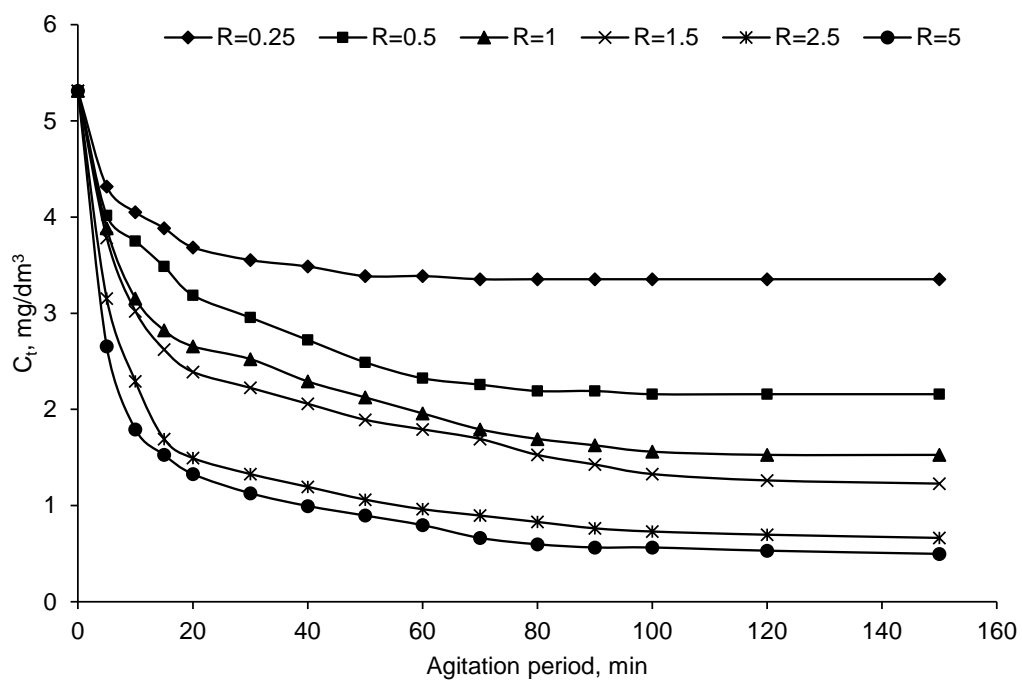

Fig. 7. Effect of contact time for chitosan-Cu(II) complex on RB29 adsorption efficiency (concentration of $\mathrm{H}_{2} \mathrm{O}_{2}-100 \mathrm{mg} / \mathrm{dm}^{3}$ )

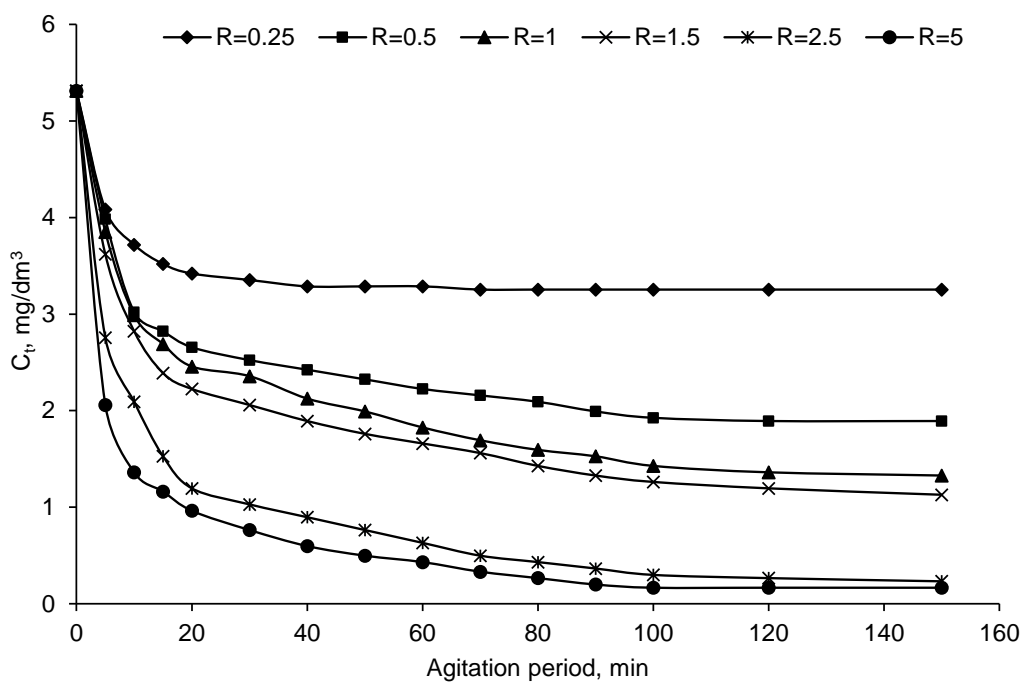

Fig. 8. Effect of contact time for chitosan-Cu(II) complex on RB29 adsorption efficiency (concentration of $\mathrm{H}_{2} \mathrm{O}_{2}-400 \mathrm{mg} / \mathrm{dm}^{3}$ )

In Figure 4, the effect of contact time on adsorption of the RB29 by chitosan $-\mathrm{Cu}$ (II) complex is shown in the presence of $10 \mathrm{mg} \mathrm{H} \mathrm{H}_{2} \mathrm{O}_{2} / \mathrm{dm}^{3}$. The final concentration of the RB after 60 min of contact time, at $R=0.25$, reached $3.58 \mathrm{mg} / \mathrm{dm}^{3}$. The adsorption capacity of chitosan- $\mathrm{Cu}$ complex with $10 \mathrm{mg} \mathrm{H}_{2} \mathrm{O}_{2} / \mathrm{dm}^{3}$ reached $6.90 \mathrm{mg} / \mathrm{g}$. Similarly as without $\mathrm{H}_{2} \mathrm{O}_{2}$ (Fig. 3), final concentration of dye decreased upon increasing $R$. 
As shown in Fig. 5, final concentration of dye at $R=0.25$ reached a steady state after $40 \mathrm{~min}$. Upon increasing $R$, the time required to reach equilibrium increased. At equilibrium, in the presence of $20 \mathrm{mg} \mathrm{H}_{2} \mathrm{O}_{2} / \mathrm{dm}^{3}$, the dye concentrations decreased from $3.55 \mathrm{mg} / \mathrm{dm}^{3}$ to $0.92 \mathrm{mg} / \mathrm{dm}^{3}$ when $R$ increased from 0.25 to 5 . The effect of contact time for chitosan- $\mathrm{Cu}$ (II) complex at $40 \mathrm{mg} \mathrm{H}_{2} \mathrm{O}_{2} / \mathrm{dm}^{3}$ is shown in Fig. 6. The final concentration of dye reached $0.73 \mathrm{mg} / \mathrm{dm}^{3}$ at $R=5$. The final dye concentration continued to decrease upon increasing $R$. Figure 7 shows the final concentration of the reactive dye for chitosan- $\mathrm{Cu}$ (II) complex at $100 \mathrm{mg} \mathrm{H}_{2} \mathrm{O}_{2} / \mathrm{dm}^{3}$. Final dye concentrations at each $R$ are lower than for $40 \mathrm{mg} \mathrm{H}_{2} \mathrm{O}_{2} / \mathrm{dm}^{3}$ in the solution. According to Figure 8 , at $R=5$, the final concentration of the RB reached $0.16 \mathrm{mg} / \mathrm{dm}^{3}$ when concentration of $\mathrm{H}_{2} \mathrm{O}_{2}$ increased to $400 \mathrm{mg} / \mathrm{dm}^{3}$. When concentration of $\mathrm{H}_{2} \mathrm{O}_{2}$ in the solution was $800 \mathrm{mg} / \mathrm{dm}^{3}$, the final dye concentration at $R=5$ reached zero after 50 min (Fig. 9).

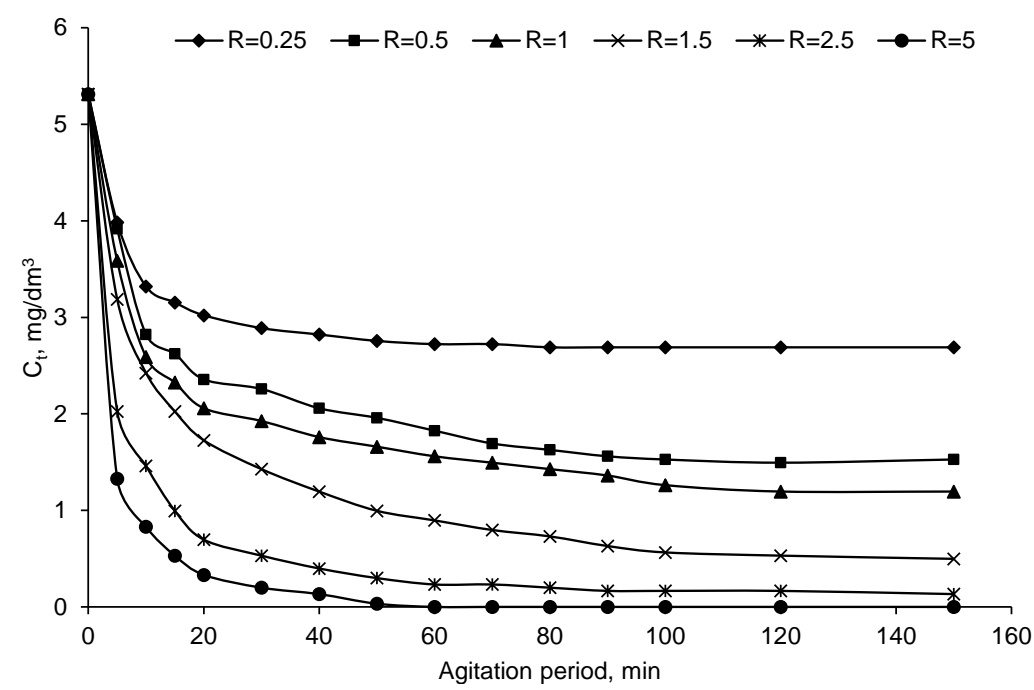

Fig. 9. Effect of contact time for chitosan-Cu(II) complex on RB29 adsorption efficiency (concentration of $\mathrm{H}_{2} \mathrm{O}_{2}-800 \mathrm{mg} / \mathrm{dm}^{3}$ )

Figures 3-9 revealed that the kinetics of RB29 adsorption occurs in two stages: the former is initial rapid adsorption related to the instantaneous external surface adsorption of RB29. The latter slower stage is a gradual adsorption that takes place before RB29 uptake attains equilibrium. The high adsorption rate during the initial period is due to the number of available adsorption sites of the bare surface of adsorbents. As these sites progressively covered, the adsorption rate decreased. The same observation has been reported by Filipkowska [18], McKay [19] and Kamari et al. [20].

As shown in Figure 4, the time required to reach equilibrium for chitosan with $\mathrm{Cu}$ complex and in the presence of hydrogen peroxide was about $45 \mathrm{~min}$. The amounts of 
RB 29 adsorbed on modified chitosan or $q_{e}$ parameter are considerably low. When concentration of hydrogen peroxide increased, $q_{e}$ slowly increased. For example, in the presence of $10 \mathrm{mg} \mathrm{H}_{2} \mathrm{O}_{2} / \mathrm{dm}^{3}$ and for $R=5$, the adsorption capacity was ca. $7 \mathrm{mg} / \mathrm{g}$ and in the presence of $800 \mathrm{mg} \mathrm{H}_{2} \mathrm{O}_{2} / \mathrm{dm}^{3}$ for $R=5$, it was $10 \mathrm{mg} / \mathrm{g}$. Therefore, when chitosan is modified with $\mathrm{Cu}$ complex, effect of hydrogen peroxide in adsorption of RB29 onto chitosan is not considerable.

\subsection{EFFECT OF MODIFICATION OF CHITOSAN WITH Cu(II) COMPLEX ON THE PROCESS EFFICIENCY}

Contacting chitosan with $\mathrm{Cu}$ complex before reaction with the $\mathrm{RB}$ occurred, decreased the adsorption capacity of chitosan (Figs. 3-16). One reason for this reduction may be due to occupation of available adsorption sites by $\mathrm{Cu}$ complex. Therefore, the number of adsorption sites for dye adsorption decreased.

\subsection{EFFECT OF $\mathrm{H}_{2} \mathrm{O}_{2}$ ON THE PROCESS EFFICIENCY}

As shown in Figs. 3 and 4, the effect of $\mathrm{H}_{2} \mathrm{O}_{2}$ in the presence of $\mathrm{Cu}$ complex was not considerable. Even at the lower concentrations $\left(10 \mathrm{mg} \mathrm{H}_{2} \mathrm{O}_{2} / \mathrm{dm}^{3}\right) \mathrm{H}_{2} \mathrm{O}_{2}$ has a contrary, inhibitory effect. However, the effect of $\mathrm{H}_{2} \mathrm{O}_{2}$ when chitosan was used without $\mathrm{Cu}$ complex was more significant, and generally adsorption increased upon increasing concentration of $\mathrm{H}_{2} \mathrm{O}_{2}$ (Figs. 10-16).

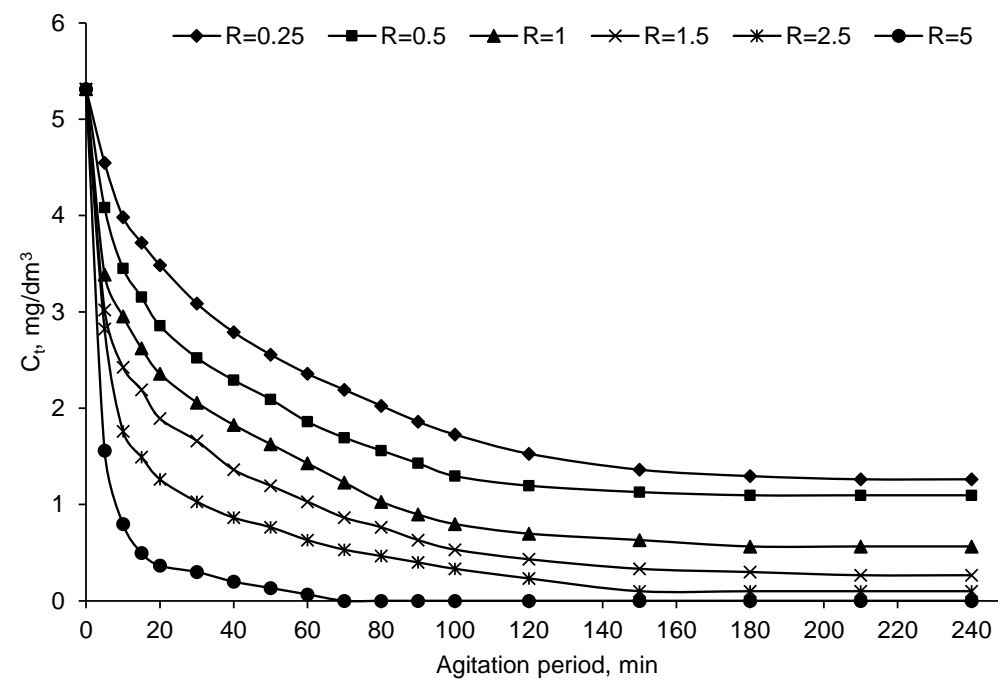

Fig. 10. Effect of contact time for chitosan without $\mathrm{Cu}$ (II) complex and without $\mathrm{H}_{2} \mathrm{O}_{2}$ on $\mathrm{RB} 29$ adsorption efficiency 


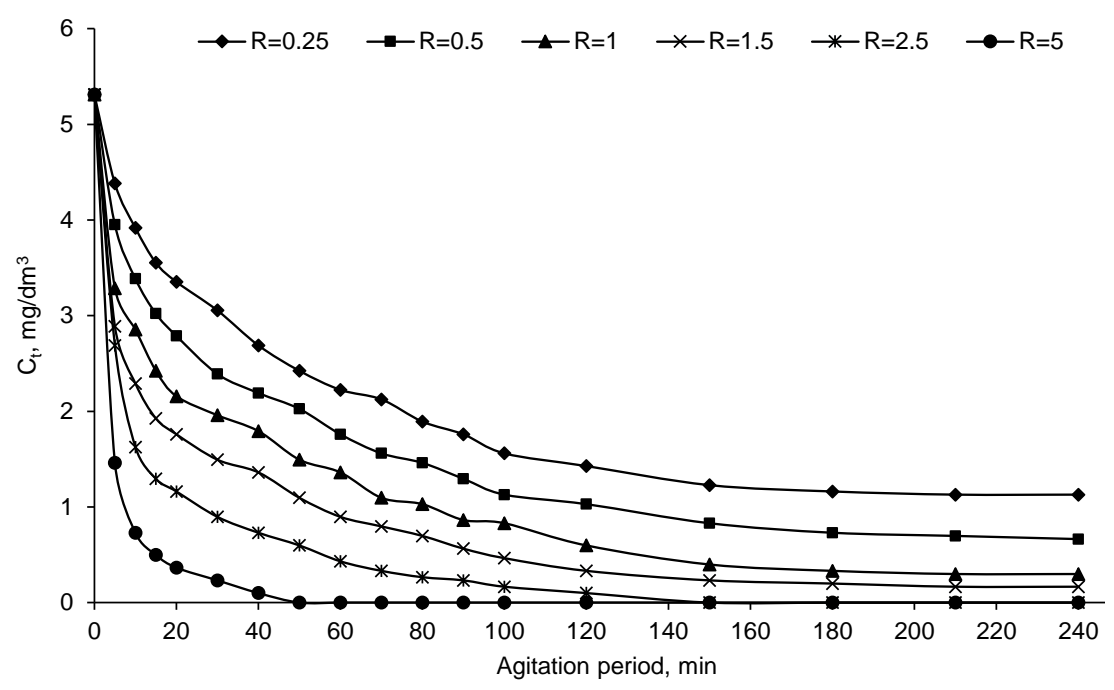

Fig. 11. Effect of contact time for chitosan without $\mathrm{Cu}$ (II) complex on RB29 adsorption efficiency $\left(\mathrm{H}_{2} \mathrm{O}_{2}-10 \mathrm{mg} / \mathrm{dm}^{3}\right)$

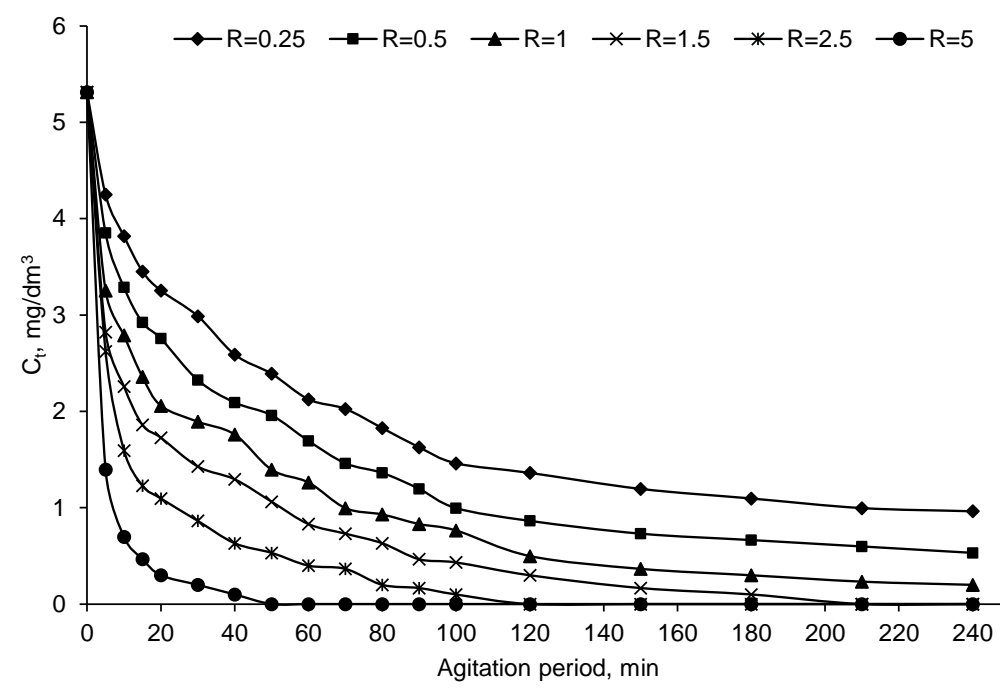

Fig. 12. Effect of contact time for chitosan without $\mathrm{Cu}$ (II) complex on RB29 adsorption efficiency (concentration of $\mathrm{H}_{2} \mathrm{O}_{2}-20 \mathrm{mg} / \mathrm{dm}^{3}$ )

Figure 10 shows the adsorption kinetics of RB29 on chitosan without $\mathrm{Cu}$ (II) complex and without addition of $\mathrm{H}_{2} \mathrm{O}_{2}$. It can be clearly seen that the final concentrations at all $R$ are lower than those presented in Fig. 3. The final dye concentrations at $R=0.25$ and $R=5$ are $1.26 \mathrm{mg} / \mathrm{dm}^{3}$ and zero, respectively. As presented in Fig. 11, the use of $10 \mathrm{mg} \mathrm{H} \mathrm{H}_{2} \mathrm{O}_{2} / \mathrm{dm}^{3}$ leads to decrease of final concentration of RB29. Thus the final dye 
concentration at $R=0.25$ is $1.12 \mathrm{mg} / \mathrm{dm}^{3}$. Upon increasing the concentration of $\mathrm{H}_{2} \mathrm{O}_{2}$, the final dye concentration continued to decrease for all $R$. The final concentration of RB29 for chitosan without $\mathrm{Cu}$ (II) complex at $20 \mathrm{mg} \mathrm{H}_{2} \mathrm{O}_{2} / \mathrm{dm}^{3}$ is shown in Fig. 12.

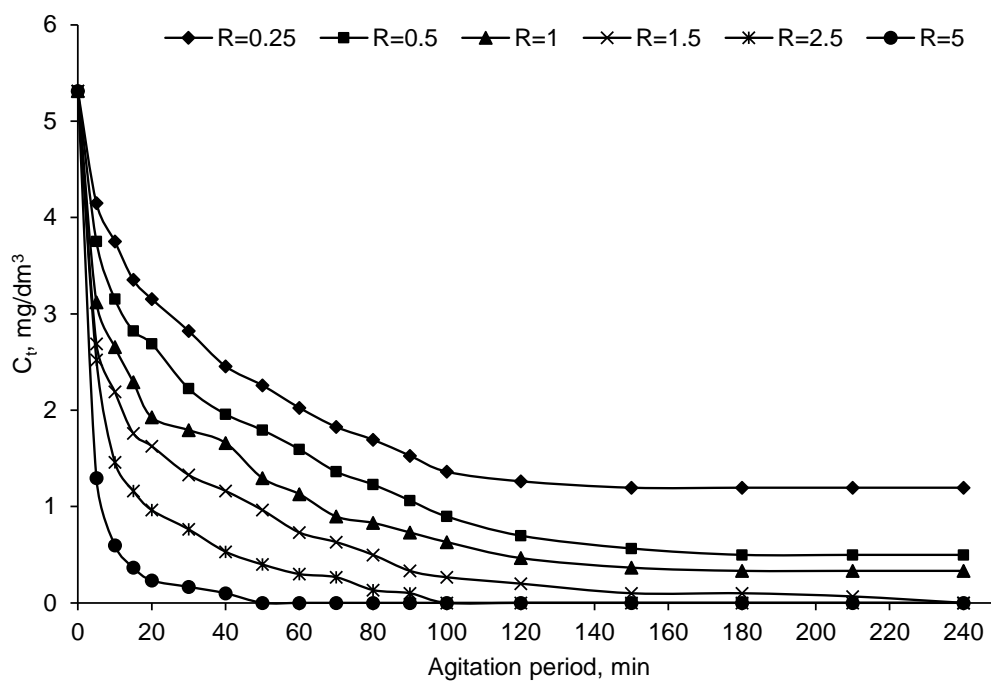

Fig. 13. Effect of contact time for chitosan without $\mathrm{Cu}$ (II) complex on RB29 adsorption efficiency (concentration of $\mathrm{H}_{2} \mathrm{O}_{2}-40 \mathrm{mg} / \mathrm{dm}^{3}$ )

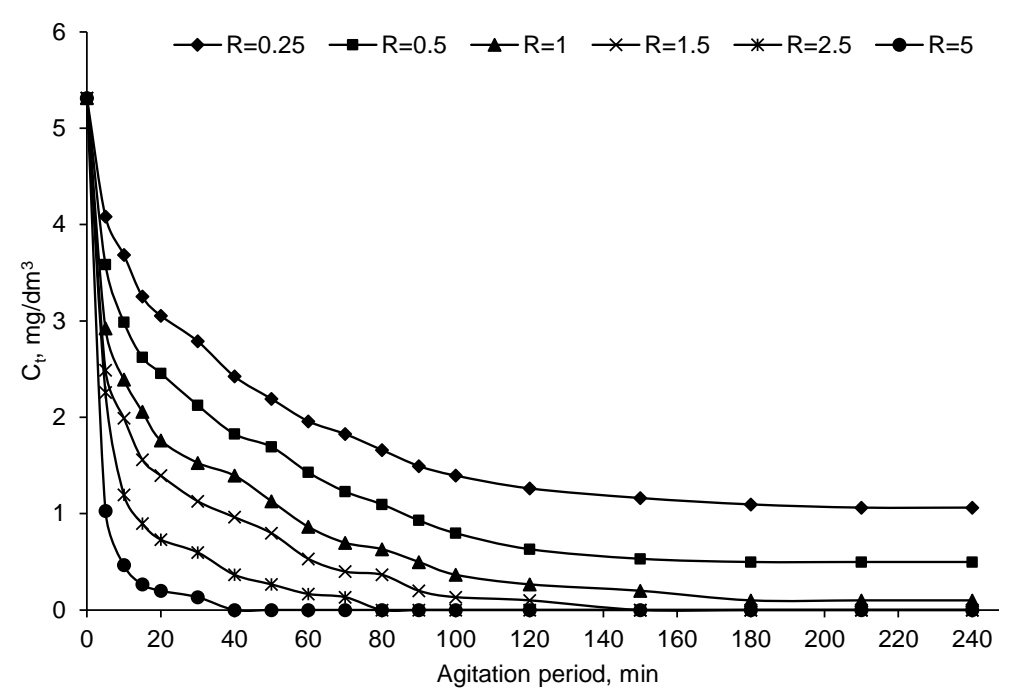

Fig. 14. Effect of contact time for chitosan without $\mathrm{Cu}(\mathrm{II})$ complex on RB29 adsorption efficiency (concentration of $\mathrm{H}_{2} \mathrm{O}_{2}-100 \mathrm{mg} / \mathrm{dm}^{3}$ ) 


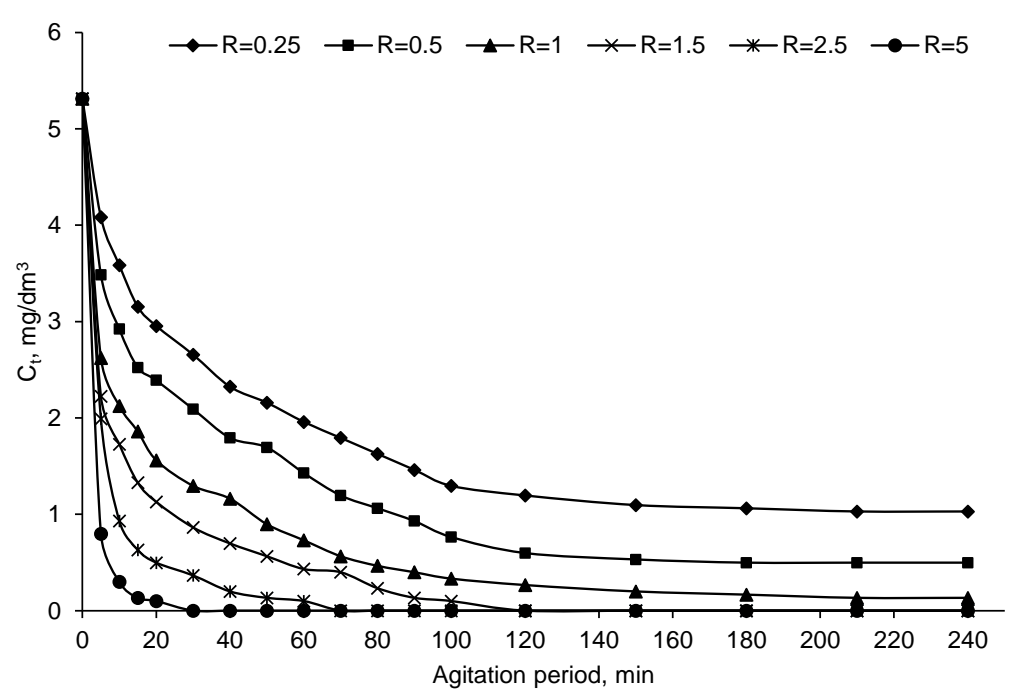

Fig. 15. Effect of contact time for chitosan without $\mathrm{Cu}(\mathrm{II})$ complex on RB29 adsorption efficiency (concentration of $\mathrm{H}_{2} \mathrm{O}_{2}-400 \mathrm{mg} / \mathrm{dm}^{3}$ )

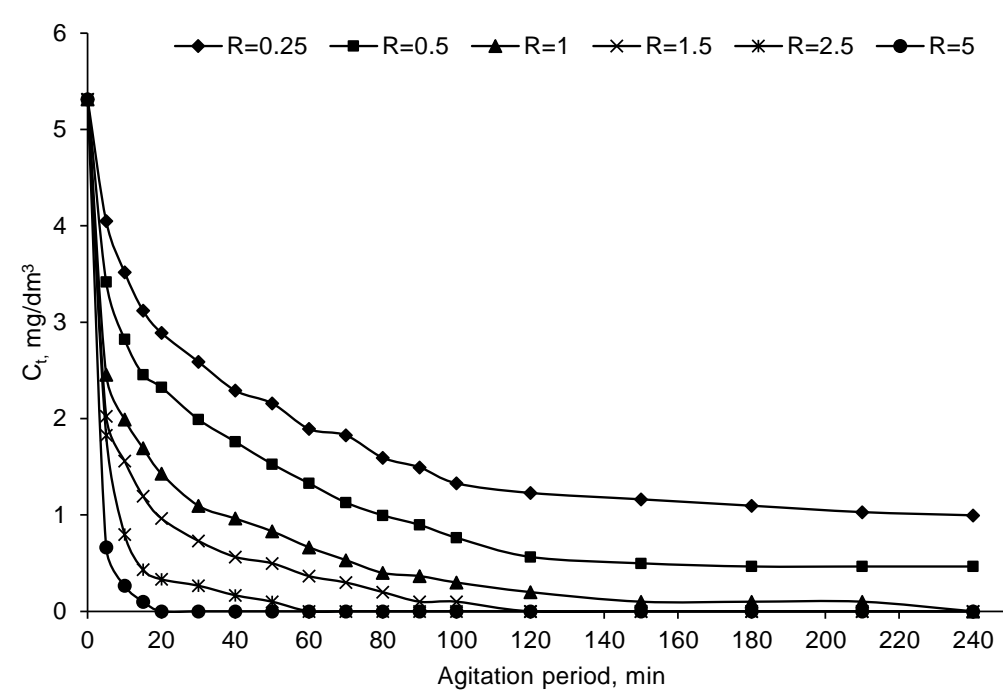

Fig. 16. Effect of contact time for chitosan without $\mathrm{Cu}(\mathrm{II})$ complex on RB29 adsorption efficiency (concentration of $\mathrm{H}_{2} \mathrm{O}_{2}-800 \mathrm{mg} / \mathrm{dm}^{3}$ )

Figures 13 and 14 show the adsorption kinetics of RB29 on chitosan without $\mathrm{Cu}(\mathrm{II})$ complex, in the presence of 40 and $100 \mathrm{mg} \mathrm{H}_{2} \mathrm{O}_{2} / \mathrm{dm}^{3}$, respectively. The final dye concentrations at each $R$ at $100 \mathrm{mg} \mathrm{H}_{2} \mathrm{O}_{2} / \mathrm{dm}^{3}$ are lower than those for $40 \mathrm{mg} \mathrm{H}_{2} \mathrm{O}_{2} / \mathrm{dm}^{3}$. As shown in Fig. 15, upon increasing concentration of $\mathrm{H}_{2} \mathrm{O}_{2}$ to $400 \mathrm{mg} \mathrm{H}_{2} \mathrm{O}_{2} / \mathrm{dm}^{3}$, the final concentration of RB29 at $R$ equal to 1.5, 2.5 and 5 reached zero after 120, 60 and $20 \mathrm{~min}$, 
respectively. The results of removal of RB29 by chitosan in the presence of $800 \mathrm{mg}$ $\mathrm{H}_{2} \mathrm{O}_{2} / \mathrm{dm}^{3}$ are shown in Fig. 16. The final dye concentration at $R$ equal to 1, 1.5, 2.5 and 5 reaches zero at steady state conditions.

Increasing the adsorption rate in the presence of $\mathrm{H}_{2} \mathrm{O}_{2}$ without $\mathrm{Cu}$ complex is probably due to the fact that both oxidation and adsorption processes effectively eliminate the reactive dye, but when $\mathrm{Cu}$ complexes are bound with chitosan, a lot of adsorption sites get saturated with these complexes. Thus not much space remains for adsorption of reactive dye and effective dye removal occurs only through oxidation. Therefore, in this case the overall removal efficiencies decreased comparing with the case where $\mathrm{Cu}$ complexes were not used.

Effect of $\mathrm{pH}$ on the process efficiency. $\mathrm{pH}$ is one of important parameters controlling the adsorption process, strongly affecting the adsorption capacity of chitosan. Figures 17 and 18 show the effect of $\mathrm{pH}$ on the adsorption of RB29 on chitosan. It can be clearly seen that the rate of dye uptake increased as $\mathrm{pH}$ decreased, which is in accordance to other authors [10]. The maximum binding for chitosan was observed at $\mathrm{pH} 2$.

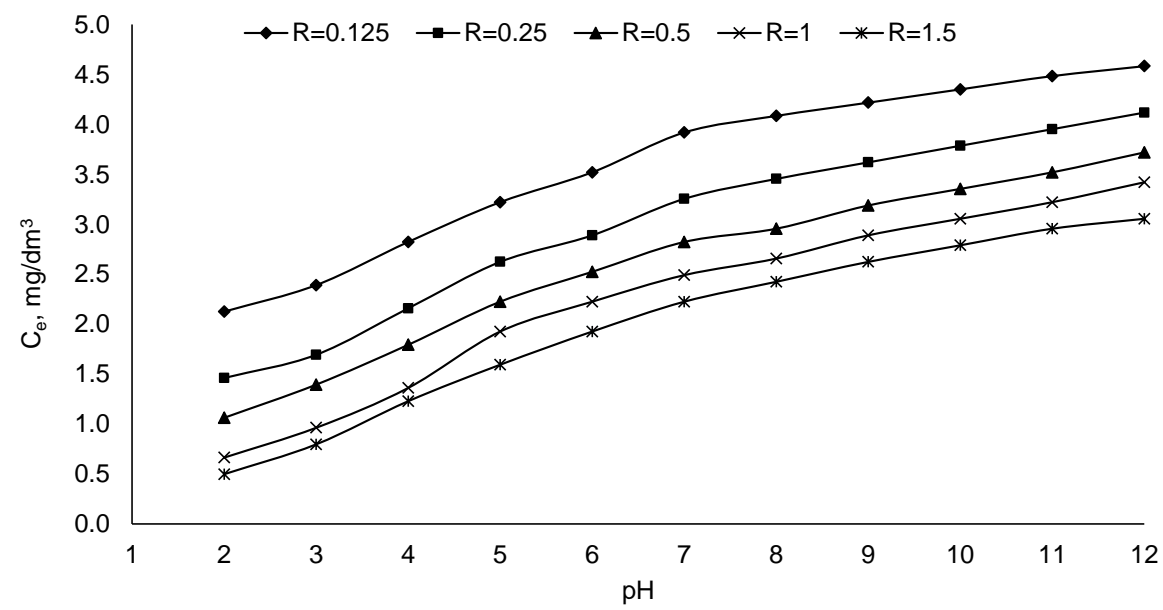

Fig. 17. Effect of $\mathrm{pH}$ for chitosan without $\mathrm{Cu}(\mathrm{II})$ complex on RB29 adsorption efficiency

As shown in Fig. 2, $-\mathrm{SO}_{3}-$ groups are present in the structures of RB29. These groups make the dyestuff more acidic. Amino group in the structure of chitosan has a great capability to adsorb contaminants due to its Lewis base character. This group is charged positively for chitosan in aqueous solutions, and thus electrostatic interactions occur between these positive charges with negative charges in the structures of RB29; amino groups in the structure of chitosan are more positively charged at lower $\mathrm{pHs}$ [21]. Thus, more electrostatic interaction at lower pHs occurs between these positively charged amino groups with $-\mathrm{SO}_{3}-$ groups in the structures of these dyestuffs. 


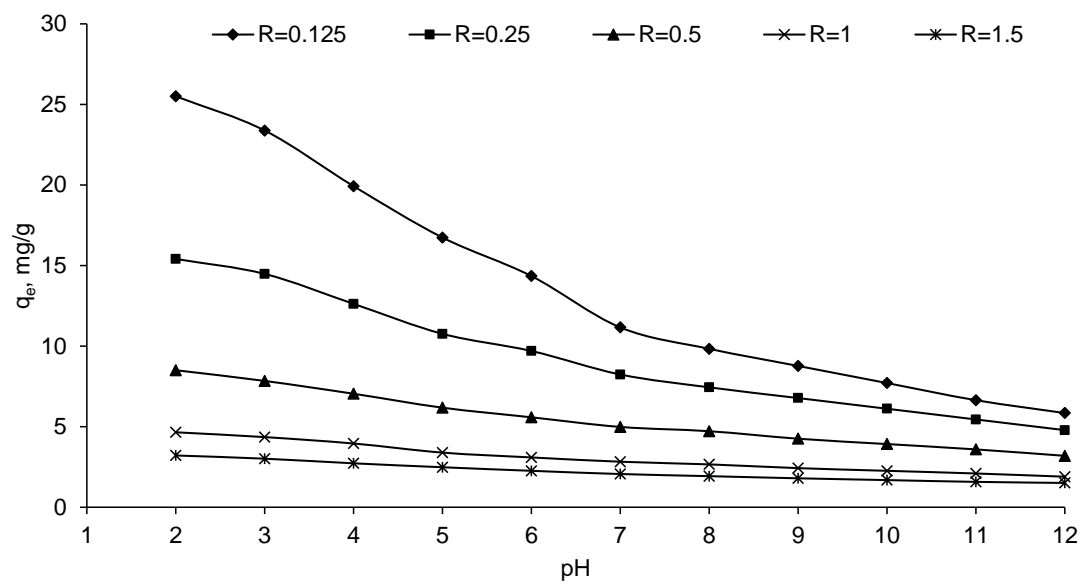

Fig. 18. Effect of $\mathrm{pH}$ for chitosan without $\mathrm{Cu}(\mathrm{II})$ complex on adsorption capacity towards $\mathrm{RB} 29$

\subsection{ADSORPTION ISOTHERMS}

The experimental data were fitted to Langmuir [22] and Freundlich [23] isotherm models. Although the Langmuir and Freundlich isotherms were firstly introduced about 90 years ago, they still remain the two most commonly used sorption isotherm equations. Their success undoubtedly reflects their ability to fit a wide variety of sorption data quite well. The Langmuir model represents chemisorption on a set of well-defined localized sorption sites, having the same sorption energies independent of surface coverage and no interaction between adsorbed molecules. The Langmuir isotherm assumes monolayer coverage of sorbate onto sorbent. The Freundlich isotherm gives an expression encompassing the surface heterogeneity and the exponential distribution of active sites and their energies. This isotherm does not predict any saturation of the sorbent surface; thus infinite surface coverage is predicted, indicating physical sorption on the surface. Thus the experimental adsorption data were analyzed according to Langmuir, Freundlich and BET isotherm models.

Langmuir isotherm. The Langmuir (1918) theory was based on the assumption that adsorption was a type of chemical combination or process and the adsorbed layer was unimolecular [19]. The theory assumes:

- There is a uniform energy of adsorption on the surface.

- Maximum adsorption corresponds to a saturated monolayer of solute molecules on the surface.

- There is no transmigration of adsorbate in the plane of the surface.

In general, the Langmuir model assumes that the adsorbent surface has adsorption sites with identical energy and each adsorbed molecule makes part of a single site, thus predicting the formation of adsorbate monolayer covering on adsorbent surface [24]. 
The Langmuir isotherm is described by the equation $[25,26]$ :

$$
Q_{e}=\frac{Q_{\max } K_{L} C_{e}}{1+K_{L} C_{e}}
$$

After linearization it takes the form of $[27,16]$ :

$$
\frac{C_{e}}{Q_{e}}=\frac{1}{Q_{\max } K_{L}}+\frac{C_{e}}{Q_{\max }}
$$

where $Q_{e}$ is the equilibrium RB29 concentration in the solid phase (adsorption capacity) $(\mathrm{mg} / \mathrm{g}), C_{e}$ is the equilibrium concentration of RB29 $\left(\mathrm{mg} / \mathrm{dm}^{3}\right)$ in the liquid phase, $Q_{\max }$ $(\mathrm{mg} / \mathrm{g})$ is the maximum monolayer adsorption capacity, $K_{L}\left(\mathrm{dm}^{3} / \mathrm{mg}\right)$ is the Langmuir sorption equilibrium constant. A linearized plot of $C_{e} / q_{e}$ against $C_{e}$ gives $Q_{\max }$ and $K_{L}$.

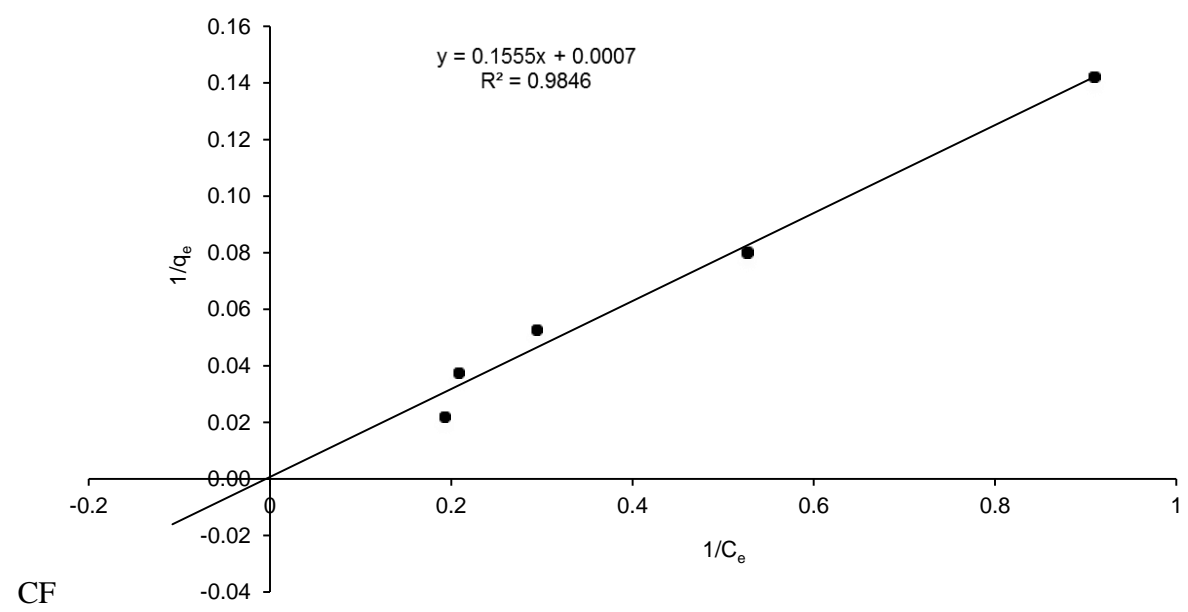

Fig. 19. Langmuir adsorption isotherm of RB29 on chitosan

Figure 19 shows the Langmuir isotherm of the RB on chitosan, its parameters are given in Table 1.

Table 1

Constants of the Langmuir, Freundlich and BET adsorption isotherms for RB29 with chitosan

\begin{tabular}{|c|c|c|c|c|c|c|c|c|}
\hline \multicolumn{2}{|c|}{ Freundlich isotherm } & \multicolumn{3}{c|}{ Langmuir isotherm } & \multicolumn{3}{c|}{ BET isotherm } \\
\hline $\begin{array}{c}K_{f} \\
{[\mathrm{mg} \mathrm{RB29/g} \mathrm{chitosan]}} \\
{\left[\mathrm{dm}^{3} \text { water/mg RB29] }\right.}\end{array}$ & $n$ & $R^{2}$ & $\begin{array}{c}Q_{\max } \\
{[\mathrm{mg} / \mathrm{g}]}\end{array}$ & $\begin{array}{c}K_{L} \\
{\left[\mathrm{dm}^{3} / \mathrm{mg}\right]}\end{array}$ & $R^{2}$ & $k b$ & $\begin{array}{c}Q_{\max } \\
{[\mathrm{mg} / \mathrm{g}]}\end{array}$ & $R^{2}$ \\
\hline 6.17 & 0.96 & 0.98 & 0.0047 & 1376 & 0.93 & 4.43 & 15.11 & 0.76 \\
\hline
\end{tabular}


Freundlich isotherm. The other well-known isotherm, which is frequently used to describe the adsorption behavior, is the Freundlich isotherm. The amount of adsorbed material is the summation of adsorption on all sites. The Freundlich isotherm describes reversible adsorption and is not restricted to the formation of the monolayer. This empirical equation takes the form [26]:

$$
Q_{e}=K_{F} C_{e}^{1 / n}
$$

and after linearization:

$$
\ln Q_{e}=\frac{1}{n} \ln C_{e}+\ln K_{F}
$$

where $K_{F}$ is the Freundlich constant representing the sorption capacity, $n$ is the constant depicting the sorption intensity and $C_{e}$ is the equilibrium concentration of RB29.

Freundlich isotherm of the RB on chitosan is shown in Fig. 20 (cf. Table 1).

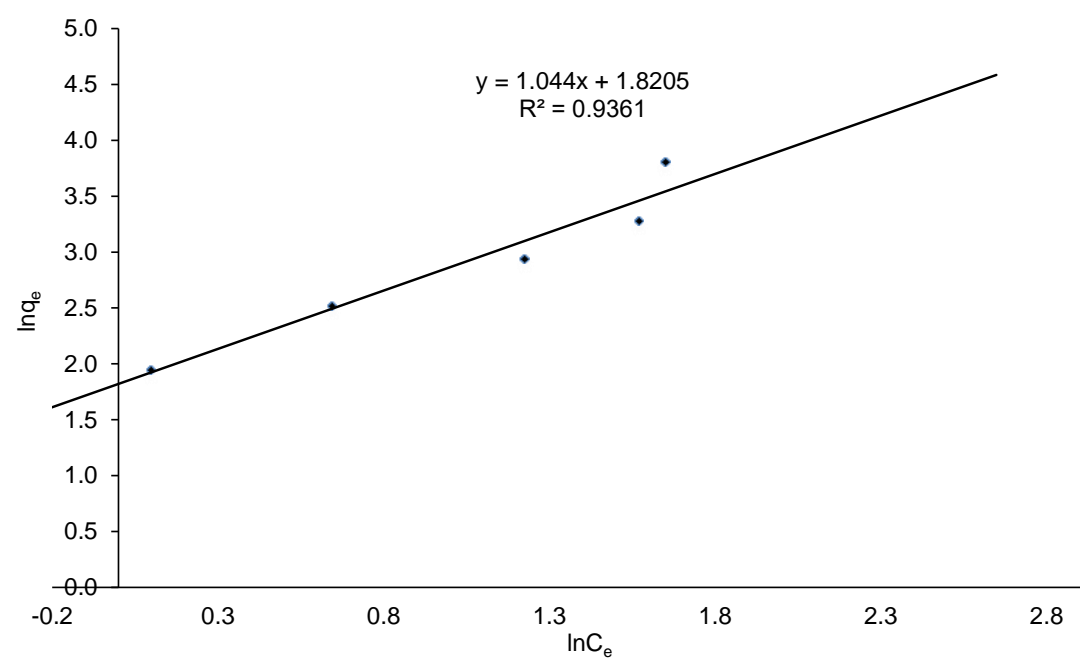

Fig. 20. Freundlich adsorption isotherm of the RB29 on chitosan

This is a more general, multilayer model. It assumes that the Langmuir isotherm applies to each layer and that no transmigration occurs between layers. It also assumes that there is equal energy of adsorption for each layer except for the first layer.

The Brunauer-Emmett-Teller (BET) equation is:

$$
\frac{Q_{\max } K_{b} C_{e}}{\left(C_{s}-C_{e}\right)\left(1+\left(K_{b}=1\right) \frac{C_{e}}{C_{s}}\right)}
$$


After linearization it takes the form:

$$
\frac{C_{e}}{Q_{e}\left(C_{s}-C_{e}\right)}=\frac{1}{K_{b} Q_{\max }}+\frac{K_{b}-1}{K_{b} Q_{\max }} \times \frac{C_{e}}{C_{s}}
$$

where $C_{s}$ is the concentration at which all layers are filled; $K_{b}$ is the BET constant expressing the energy of interaction with surface and $C_{e}$ is the equilibrium concentration of RB29. Its assumptions are:

- Surface of the adsorbent is homogeneous.

- Enthalpy of adsorption is the same for every layer.

- Energy of adsorption is the same for layers other than the first one.

- A new layer can start before another is finished.

The BET isotherm of the RB29 on chitosan is shown in Fig. 21 (cf. Table 1). The correlation coefficients in Table 1 indicate that the Freundlich and BET isotherm data are not well correlated compared to the Langmuir correlation coefficients.

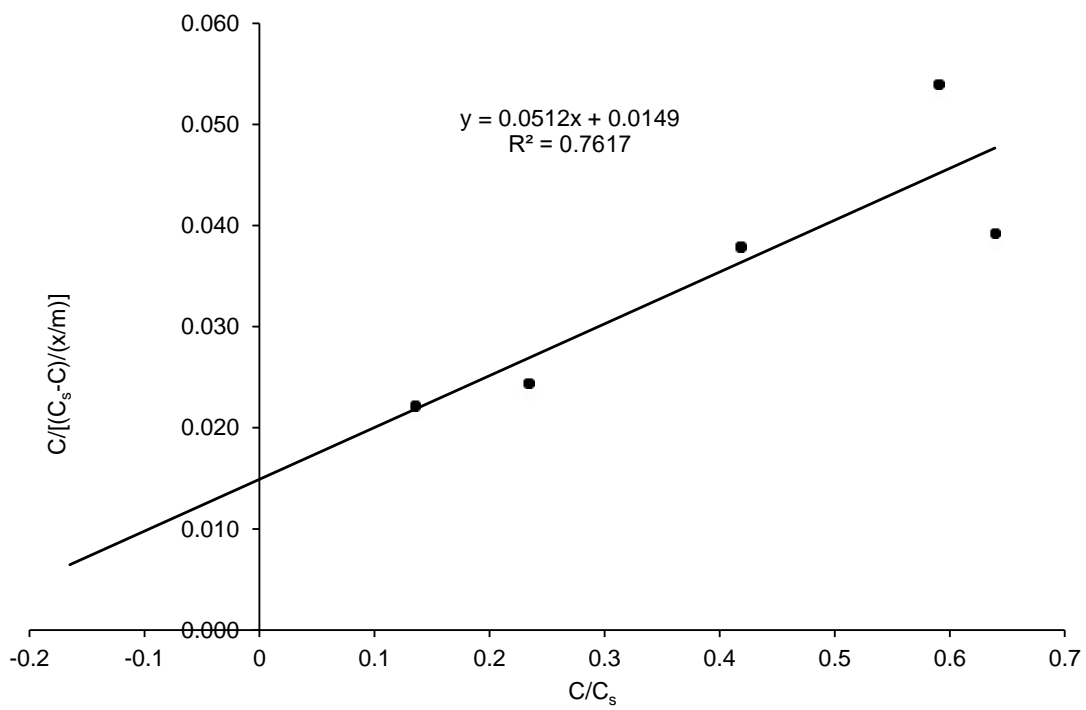

Fig. 21. BET adsorption isotherm of the RB29 on chitosan

Based on the linear isotherm equations, the correlation coefficients $R^{2}$ have been determined (Table 1). The plots in Fig. 19 demonstrate that the Langmuir equation provides an accurate description of the experimental data, which is further confirmed by the extremely high values of the correlation coefficients for the dye-chitosan systems. The high degree of correlation for the linearized Langmuir relationship suggests that a single surface reaction with constant activation energy is the predominant adsorption step and possibly the predominant rate controlling. These results are in accordance with 
those of Cheun et al. [28] who investigated enhancing the adsorption capacities of acid dyes by nanochitosan and reported that Langmuir isotherm was appropriate to describe the adsorption characteristics of dyes on nanochitosan.

\section{CONCLUSION}

Performance of chitosan and modified chitosan as adsorbents in the presence of $\mathrm{H}_{2} \mathrm{O}_{2}$ to remove the RB29 from aqueous solution has been investigated in this study. Equilibrium isotherms have been recorded and analyzed using Langmuir, Freundlich and BET equations.

The adsorption capacity of chitosan with $\mathrm{Cu}$ complexes was lower than that of chitosan without $\mathrm{Cu}$ complexes. This may be due to occupation of adsorption sites with $\mathrm{Cu}$ complexes.

Effect of $\mathrm{H}_{2} \mathrm{O}_{2}$ on adsorption efficiency when chitosan is used without $\mathrm{Cu}$ complexes is more considerable. This may be due to the fact that in such cases both adsorption and oxidation processes contribute to dye removal.

Adsorption capacity of chitosan towards the RB29 was higher at lower pH when more electrostatic interaction occur between positively charged amino groups with $-\mathrm{SO}_{3}-$ groups in the structures of these dyestuffs.

The Langmuir isotherm equation gave the best correlation for the adsorption of the RB29 on chitosan.

\section{REFERENCES}

[1] Zollinger H., Color Chemistry. Synthesis, Properties, and Applications of Organic Dyes and Pigments, 3rd Ed., Wiley-VCH, Weinheim 2001.

[2] Pagga U., TAEgER K., Development of a method for adsorption of dyestuffs on activated sludge, J. Water Res., 1994, 28 (5), 1051.

[3] Gómez V., LARREChi M.S., CALlao M.P., Kinetic and adsorption study of acid dye removal using activated carbon, J. Chemosphere, 2007, 69 (7), 1151.

[4] Robinson T., McMullan G., Marchant R., Nigam P., Remediation of dyes in textile effluent. A critical review on current treatment technologies with a proposed alternative, J. Biores. Technol., 2001, 77 (3), 247.

[5] Kumar M.N.V., SRidhari T.R., Bhavani K.D., DutTa P.K., Trends in color removal from textile mill effluents, J. Color., 1998, 45 (38), 25.

[6] SHEn C., Song S., ZANG L., KANG X., Wen Y., Liu W., Fu L., Efficient removal of dyes in water using chitosan microsphere supported cobalt(II) tetrasulfopht halocyanine with $\mathrm{H}_{2} \mathrm{O}_{2}$, J. Hazard Mater., 2010, 177 (1-3), 560.

[7] CRINI G., Non-conventional low-cost adsorbents for dye removal. A review, J. Bioresour. Technol., 2006, 97 (9), 1061.

[8] Mahstahbinti H., Adsorption of reactive azo dyes on chitosan/oil-palm ash composite adsorbent. Batch and continuous studies, Universiti Sains Malaysia, 2008. 
[9] NAghiZADEh A., NASSER S., NAZMARA S., Removal of trichloroethylene from water by adsorption onto multiwall carbon nanotubes, J. Environ. Health Sci. Eng., 2011, 8 (4), 317.

[10] GeORge Z., KyZas H., Nikolaos K, LaZARIDIS S., Reactive and basic dyes removal by sorption onto chitosan derivatives, J. Colloid. Interface Sci., 2009, 331 (1), 32.

[11] Dehghani M.H., NaghiZadeh A., Rashidi A.M., Derakhshani E., Adsorption of reactive blue 29 dye from aqueous solution by multi-wall carbon nanotubes, J. Desal. Water Treatment, 2013, 51 (40-42), 7655.

[12] Lazaro M.J.M., Leal D.M.F., Piehl L.L., Celis D.R., Buldain G.Y., Dallorto V.C., Studies on the activation of hydrogen peroxide for color removal in the presence of a new $\mathrm{Cu}(\mathrm{II})$-polyampholyte heterogeneous catalyst, J. Appl. Catal. B: Environ., 2008, 82, 273.

[13] Honarkar H., Barikani M., Applications of biopolymers I. Chitosan, Monatsh Chem., 2009, 140, 1403.

[14] Bansal V., Sharma P.K., Sharma N., Prakash P., Malviya R., Applications of chitosan and chitosan derivatives in drug delivery, J. Adv. Biol. Res., 2011, 5 (1), 28.

[15] Gooday G.W., Jeuniaux C., MuZZarelli R., Chitin in Nature and Technology, Vol. 1, 1st Ed., Plenum Press, New York 1986.

[16] WAN NGAH W.S., KAMARI A., KOAY Y.J., Equilibrium and kinetics studies of adsorption of copper(II) on chitosan and chitosan/PVA beads, Int. J. Biol. Macromol., 2004, 34 (3), 155.

[17] Sakkayawong N., ThiRavetyan P., NakbanPote W., Adsorption mechanism of synthetic reactive dye wastewater by chitosan, J. Colloid Interface Sci., 2005286 (1), 36.

[18] FiLIPKOWsKa U., Efficiency of reactive dyes adsorption onto chitin, chitosan and chitosan beads, Polish Chitin Society, Monograph 11, 2006, Łódź, Poland.

[19] MCKay G., PORTER J.F., Prasad G.R., The removal of dye colours from aqeous solutions by adsorption on low-cost materials, J. Water, Air, Soil Poll., 1999, 114 (3-4), 423.

[20] KAMARI A., WAN NGAH W.S., Isotherm, kinetic and thermodynamic studies of lead and copper uptake by $\mathrm{H}_{2} \mathrm{SO}_{4}$ modified chitosan, J. Coll. Surf. B: Biointerfaces, 2009, 73 (2), 257.

[21] Akкaya G., Uzun I., Guzel F., Kinetics of the adsorption of reactive dyes by chitin, J. Dyes Pigm., 2007, 73 (2), 168.

[22] LANGMUIR I., The adsorption of gases on plane surfaces of glass, mica and platinum, J. Amer. Chem. Soc., 1918, 40 (9), 1361.

[23] FreundLich H.M.F., Over the adsorption in solution, J. Phys. Chem., 1906, 57A, 385.

[24] Arica M.Y., Yalmaz E., Yalcin E., Bayramoglu G., Surface properties of reactive yellow 2 immobilized pHEMA and HEMA/chitosan membranes: characterization of their selectivity to different proteins, J. Membr. Sci., 2004, 240 (1-2), 167.

[25] Naghizadeh A., Nasseri S., Rashidi A.M., ReZaei Kalantary R., Nabizadeh R., MahVi A.H., Adsorption kinetics and thermodynamics of hydrophobic natural organic matters (NOMs) removal from aqueous solution by multi-wall carbon nanotubes, J. Water Sci. Technol.: Water Supply, 2013, 13 (8), 273.

[26] Cheung W.H., Szeto Y.S., McKay G., Intraparticle diffusion processes during acid dye adsorption onto chitosan, J. Bioresource Technol., 2007, 98 (15), 2897.

[27] Kamari A., Wan Ngah W.S., Chong M.Y., Cheah M.L., Sorption of acid dyes onto GLA and $\mathrm{H}_{2} \mathrm{SO}_{4}$ cross-linked chitosan beads, J. Desal., 2009, 249 (3), 1180.

[28] Cheung W.H., SZETo Y.S., MCKAY G., Enhancing the adsorption capacities of acid dyes by chitosan nano particles, J. Biores. Technol., 2009, 100 (3), 1143. 